\title{
Colgajo libre osteocutáneo escapular en el tratamiento diferido de herida por arma de fuego
}

\section{Scapular osteocutaneous free flap in the deferred treatment of firearm wounds}

\author{
D. Durán Moreno', A. Cabello Serrano², A.B. Marín Fernández², C. Bailon Berrio², \\ J.A. Rodríguez Ruiz',3
}

Resumen: Las heridas por arma de fuego de velocidad alta o intermedia, provocan importantes pérdidas de tejido óseo y blando. El tratamiento diferido de estos casos (tratamiento reconstructivo) requiere el aporte de tejido sano de regiones distantes mediante técnicas microquirúrgicas en la mayoría de las ocasiones. Exponemos la utilidad del colgajo osteocutáneo escapular(COE) para la reconstrucción de defectos óseos mandibulares laterales con amplio defecto cutáneomucoso. Citamos detalles técnicos de la realización del colgajo ilustrados con la presentación de un caso clínico de un varón de 19 años con herida por arma de fuego en tercio inferior de la región lateral izquierda. Pérdida ósea del cuerpo mandibular y cutánea de la mejilla y región yugal ipsilateral.

El tratamiento inicial consistió en traqueotomía, desbridamiento de tejidos desvitalizados, ferulización dentaria, bloqueo intermaxilar, colocación de placa de reconstrucción mandibular y colgajo de avance cervico-facial para cierre del defecto cutáneo. La necrosis del colgajo de avance cervicofacial produjo comunicación orofacial. La retracción cicatricial limitó la apertura oral a $0,8 \mathrm{~cm}$. De forma diferida se procedió a colgajo osteomiocutáneo escapular-paraescapular del brazo izquierdo para reconstrución mandibular y de partes blandas intra y extraorales. Resultados satisfactorios estética y funcionalmente. Complicaciones producidas: fístula salival, desinserción del brazo largo del tríceps, y dehiscencia de herida de zona donante escapular que necesitó intervención para cierre mediante colgajo local.

Palabras clave: Herida por arma de fuego; Reconstrucción mandibular; Colgajo osteocutáneo escapular.

Recibido: 12.6 .08

Aceptado: 25.11 .08
Abstract: Firearm wounds caused by high-velocity projectiles cause enormous losses of bone and soft tissue. The deferred treatment of these cases (delayed reconstruction) in most cases requires the transfer of free tissue from other areas of the body. The use of scapular and parascapular free flaps with scapular bone for the reconstruction of large lateral mandibular defects with extensive soft-tissue avulsion is reported. The technical details of a free flap are offered with illustrations in the case report of a 19-year-old male who was shot at close range in the lower third of the left lateral face. Avulsion of the left mandibular body and soft tissue occurred in the region from the cheek to the oral commissure. The initial treatment was tracheostomy, cleaning of necrotic and devitalized tissues, wiring of a mandible-to-maxilla arch bar and intermaxillary fixation, rigid fixation with a reconstructive mandibular plate, and a regional cervical flap to close the skin wound. The cervical flap was lost and a postoperative oral-cervical fistula appeared. Scar contraction limited the mouth opening to $0.8 \mathrm{~cm}$. In deferred treatment, a scapular and parascapular free flap with scapular bone from the left shoulder was used to reconstruct the mandibular and intraoral-facial soft-tissue defects. The aesthetic and functional results were optimal. Some complications occurred: postoperative salivary fistula, deinsertion of the long head of the brachial triceps, and scapular wound dehiscence, which will be closed surgically with a local flap.

Key words: Firearm wounds; Mandibular reconstruction; Scapular free flap.

1 Médico Adjunto.

2 Médico Residente.

3 Medico Adjunto del H.U. Puerta del Mar de Cádiz.

Servicio de Cirugía Oral y Maxilofacial.

H.U. Virgen de las Nieves. Granada. España.

\section{Correspondencia:}

Juan Andrés Rodríguez Ruiz

Carretera Jaen $72-\mathrm{A}, 5^{\circ} \mathrm{C}$

18013 Granada, España

E-mail: katifa@telefonica.net 


\section{Introducción}

Las heridas por arma de fuego son poco frecuentes en nuestro medio geográfico. Pueden ser clasificadas según la velocidad del proyectil, en heridas producidas por proyectiles de alta velocidad (armas largas del ámbito militar con velocidad mayor de $300 \mathrm{~m} / \mathrm{sg}$ ), heridas por cartuchos de perdigones (escopetas de caza) con velocidad intermedia; y heridas producidas por proyectiles de baja velocidad (pistolas y revólveres con velocidad menor de $300 \mathrm{~m} / \mathrm{sg}$ ).

Tradicionalmente se consideraba que el poder lesivo del proyectil venía determinado por su masa y velocidad, las cuales determinaban el energía cinética del mismo. Pero hay otros parámetros que condicionan el daño corporal, como son la balística interna (trayectoria del proyectil en el arma), la balística externa (recorrido exterior) y la balística terminal (estudia la trasmisión de energía a los tejidos). ${ }^{1}$

En general los proyectiles de baja velocidad, producen lesiones con poca pérdida ósea y de tejidos blandos, estando las lesiones asociadas limitadas al trayecto del proyectil.

Los disparos de escopetas de caza y proyectiles de alta velocidad producen importantes pérdidas de sustancia en tejidos blandos y hueso, originando graves alteraciones anatómicas, y abundante sangrado, siendo frecuente el compromiso de la vía aérea. ${ }^{2}$

En nuestro medio son más frecuentes, las heridas por escopetas de caza, sobre todo en casos de intento de autolisis. ${ }^{1}$

En el tratamiento de las heridas por arma de fuego podemos distinguir dos fases:

1. Tratamiento inicial.

Tiene como objeto mantener la vía aérea permeable (intubación, cricotiroidotomía, traqueotomía), controlar la hemorragia (ligadura de vasos sangrantes), prevenir el choque hipovolémico, y realizar un tratamiento desbridante conservador (retirada de tejidos desvitalizados óseos y blandos) (Fig.1).

En esta fase también se realiza el tratamiento de las fracturas con reducción y fijación adecuada a la lesión. En los frecuentes casos de pérdida de sustancia ósea conviene "puentear" el defecto con una placa de reconstrucción con tornillos de bloqueo (Fig.2). El cierre primario del defecto cutáneo o mucoso debe ser un objetivo secundario sobre todo en los casos de importante défi-

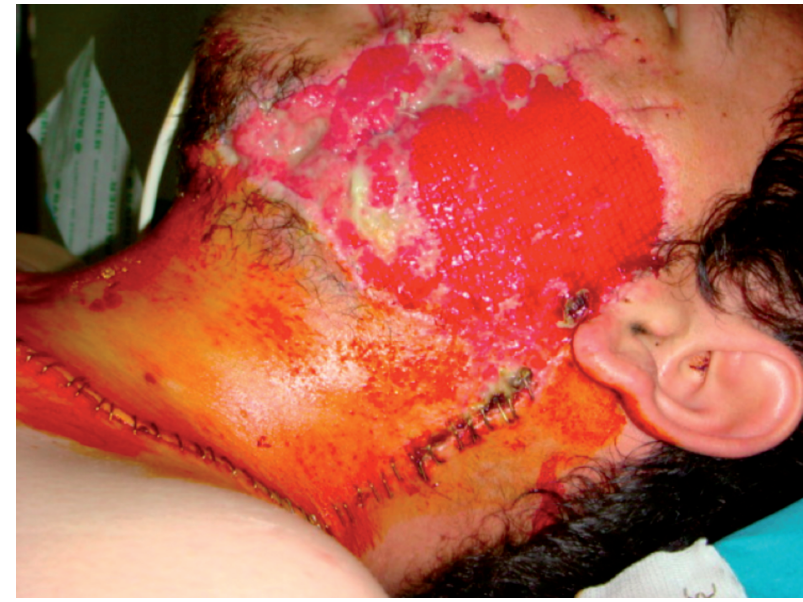

Figura 1. Imagen clínica previa a la reconstrucción microquirúrgica. La necrosis del colgajo cervical usado en el cierre primario

1. Clinical image prior to microsurgical reconstruction. Necrosure.

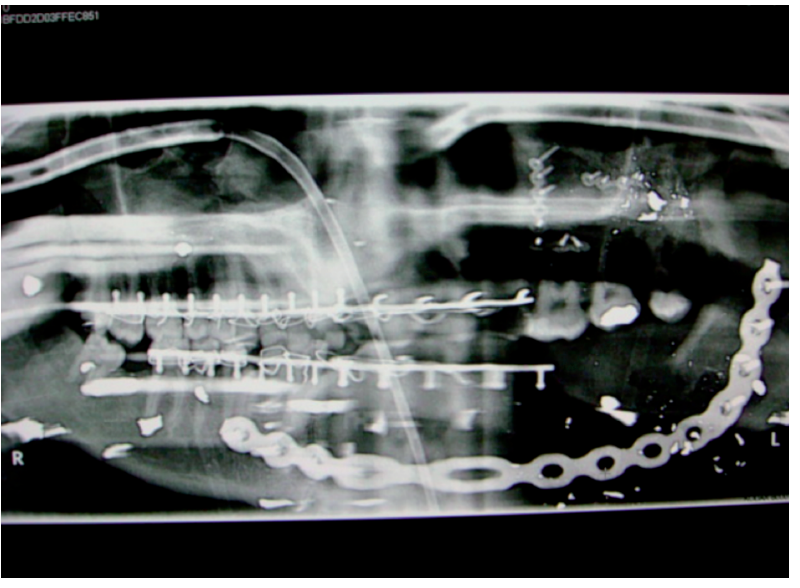

Fura 2. Ortopantomografía mostrando el defecto óseo man-

Figure 2. Orthopantomography showing the left mandibular bone defect after primary treatment.

\section{Introduction}

Firearm injuries are uncommon in our country. These wounds can be classified according to the speed of the projectile: wounds produced by high-speed projectiles (military long barrel firearms, with a projectile speed of more than $300 \mathrm{~m} / \mathrm{s}$ ), wounds produced by shot (hunting shotguns) with an intermediate projectile speed, and wounds produced by low-speed projectiles (pistols and revolvers, with a speed of less than $300 \mathrm{~m} / \mathrm{s}$ ).

It was traditionally thought that the potential for damage of the projectile was determined by its mass and speed, which determined the kinetic energy of the projectile. However, other parameters condition bodily damage, such as the internal ballistics (trajectory of the projectile in the weapon), external ballistics (trajectory after leaving the weapon), and terminal ballistics (which studies the transmission of energy to tissues). ${ }^{\text {? }}$

In general, low-speed projectiles produce injuries with little bone and soft tissue loss. The associated injuries are confined to the trajectory of the projectile.

The firing of shotguns and high-speed projectiles produces abundant loss of soft tissue and bone, originating serious anatomic disruptions and copious bleeding. Airway tract involvement is frequent. ${ }^{2}$

In our environment, wounds caused by shotguns are the most common firearm injuries, particularly cases of attempted suicide. ${ }^{1}$

Two phases can be distinguished in the treatment of firearm injuries:

1. Initial treatment

The objective is to keep the airway open (intubation, cricothyroidotomy, tracheotomy), control hemorrhage (ligation of bleeding vessels), prevent hypovolemic shock, and perform conservative debridement (removal of devi- 
cit de tejidos (en espera del tratamiento secundario).

2. Tratamiento diferido, reconstructivo o secundario.

Se realiza de 15 a 25 días después del tratamiento inicial en aquellos casos que requieren aporte de tejido mediante colgajos libres microvascularizados. Cuanto más tiempo se tarde en llevar a cabo este tratamiento más dificultades tendremos debido a la retracción de los tejidos blandos y a la adenitis reactiva cervical, sobre todo en pacientes jóvenes, que dificulta la preparación de los vasos receptores del colgajo libre.

Cuando el defecto óseo de las heridas por arma de fuego se acompaña de un gran déficit de partes blandas, con importantes comunicaciones orofaciales $\mathrm{u}$ orocervicales, el colgajo osteocutáneo escapular nos permite un tratamiento diferido o reconstructivo eficaz. Aporta hueso en longitud adecuada a la mayoría de los defectos (hasta $15 \mathrm{~cm}$ ) y con un grosor adecuado para una posterior rehabilitación implantosoportada, especialmente en sujetos jóvenes musculosos. Aporta igualmente piel y tejido subcutáneo suficiente para la reconstrucción mucosa intraoral y la cutánea cervical.

Después de repasar la técnica del colgajo osteocutáneo escapular (descrita por muchos autores de forma detaIlada), ${ }^{3,4}$ se presenta un caso clínico y se discute sobre la utilidad de esta zona donante en el tratamiento diferido de heridas por arma de fuego con gran pérdida de sustancia.

\section{Colgajo osteocutáneo escapular: detalles de la técnica}

El colgajo libre osteocutáneo escapular-paraescapular (COE) ocupa un importante lugar en la reconstrucción microquirúrgica de cabeza y cuello para defectos mixtos cutáneo-mucoso-óseos complejos. Está basado en el eje arterial: arteria axilar, arteria subescapular, arteria circunfleja escapular y arterias escapular-paraescapular.

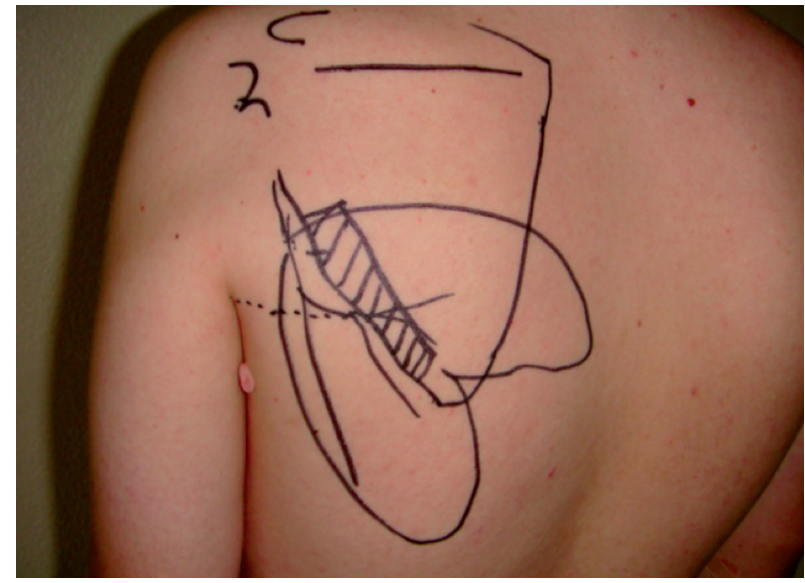

Figura 3. Dibujo del colgajo previo a la intervención. Figure 3. Drawing of the flap prior to the intervention.

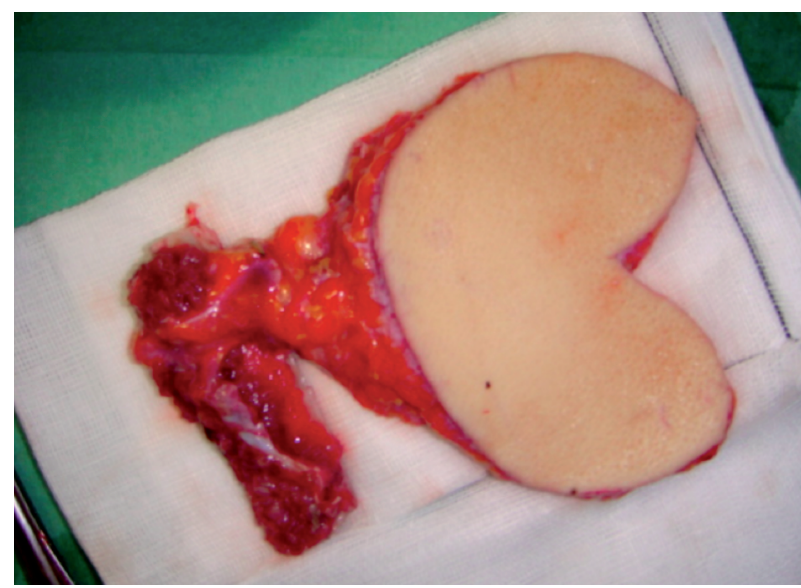

Figura 4. Cogajo libre osteocutáneo escapular previo a su traslado al lecho receptor.

Figure 4. Scapular osteocutaneous free flap before transfer to the receptor bed.

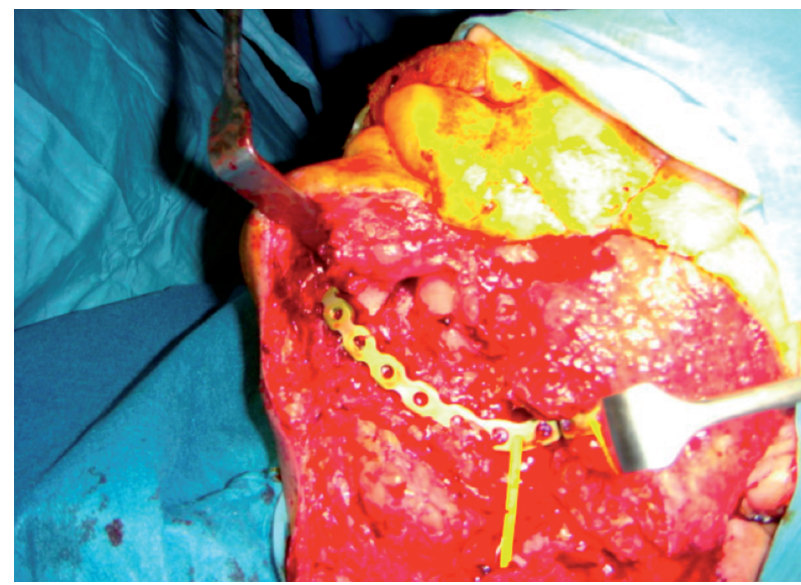

Figura 5. Defecto mandibular mucoso y cutáneo previo a la colocación del colgajo osteocutáneo escapular.

Figure 5. Mandibular mucosal and cutaneous defect before placement of the scapular osteocutaneous flap. talized bone and soft tissue) (Fig.1).

In this phase, fractures are treated by reduction and fixation adapted to the injury (Fig.2). In the frequent cases of loss of bone substance, the defect can be "bridged" with a reconstruction plate and locking screws.

Primary closure of the cutaneous or mucosal defect must be a secondary objective, particularly in cases of major tissue defects (pending secondary treatment).

2. Deferred, reconstructive, or secondary treatment This is done 15 to 25 days after the initial treatment in cases that require tissue in the form of microvascularized free flaps. The longer it takes to carry out this treatment, the greater the difficulties will be due to soft tissue retraction and cervical lymph node inflammation, especially in young patients, which makes it difficult to prepare the vessels to which the free flap will be anastomosed.

When the bone defect produced by firearm wounds is accompanied by a large soft tissue defect with considerable orofacial or orocervical openings, the scapular osteocutaneous flap makes for effective deferred or reconstructive treatment. It provides bone of suitable length for the majority of defects (up to $15 \mathrm{~cm}$ ), with an adequate thickness for a later implant-supported rehabilitation, especially in young muscular subjects. It also supplies sufficient skin and subcutaneous tissue for intraoral mucosal and cervical cutaneous reconstruction. After reviewing the scapular osteocutaneous flap tech- 
Estos defectos complejos los encontramos en los traumatismos por armas de fuego como las escopetas de perdigones (caza) y los proyectiles de alta velocidad.

Generalmente una vez decidida la realización del $\mathrm{COE}$, se dibuja el colgajo el día de antes con el paciente de pie, con el torso desnudo y los brazos colgando (Fig.3). Se suele tomar la escápula del lado contralateral al defecto. El espacio omotricipital está en el punto donde se une una línea trazada horizontalmente desde la parte más alta del pliegue axilar posterior hasta el borde lateral de la escápula. El Doppler puede ayudar a localizar las ramás arteriales a preservar.

El día de la intervención tras la disección de los vasos donantes (arterias tiroidea superior, lingual o facial) se coloca el paciente en decúbito lateral con brazo en antepulsión $90^{\circ}$, perpendicular al torax. Es útil un apoya brazos y fijar la cadera con esparadrapo a la mesa en la posición adecuada.

Levantamiento del colgajo desde distal incluyendo la fascia tóraco-dorsal sobre los músculos dorsal ancho, redondo mayor, redondo menor y trapecio. Se excluye la fascia del infraespinoso y deltoides.

En el espacio omotricipital nos desprendemos de las fascias para progresar en profundidad en el conducto omotricipital, cuyo borde superior es la fascia del músculo redondo menor y el borde inferior es la fascia del músculo redondo mayor. Por fuera tenemos la cabeza corta del músculo tríceps braquial.

Referencia constante es la cresta lateral de la escápula, pues inmediatamente adyacente a ella emerge el pedículo.

Entramos en plano areolar laxo y seccionamos los ramos vasculares directos al redondo mayor.

Cerca del la cresta lateral actuamos de dos formas, según el típo de colgajo a usar:

1. Colgajo cutáneo sin hueso (escapularparaescapular). Seccionamos las siguientes ramas de la arteria circunfleja escapular (ACE):

- Pedículo nutricio óseo.

- Rama descendente.

- Rama del infraespinoso.

- Rama circunfleja anterior de la escápula para el músculo subescapular.

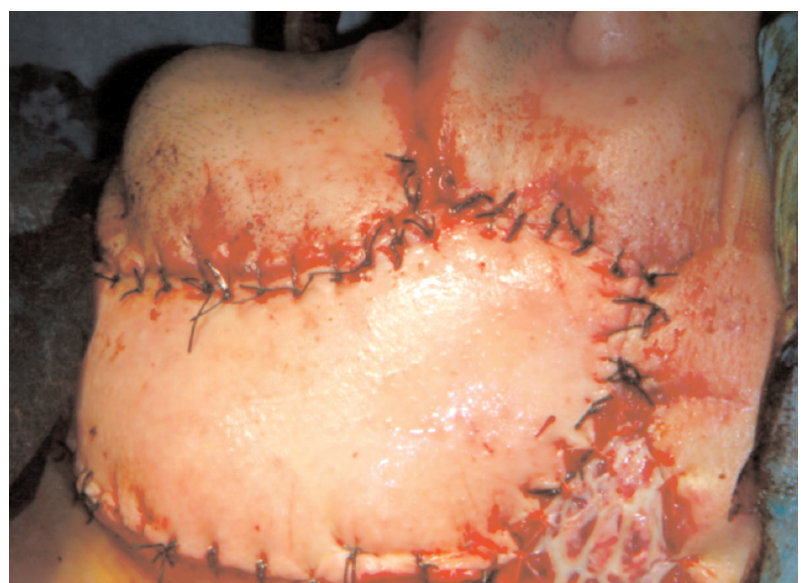

Figura 6. Postoperatorio inmediato del colgajo osteocutáneo escapular.

Figure 6. Immediate postoperative period of the scapular osteocutaneous flap.

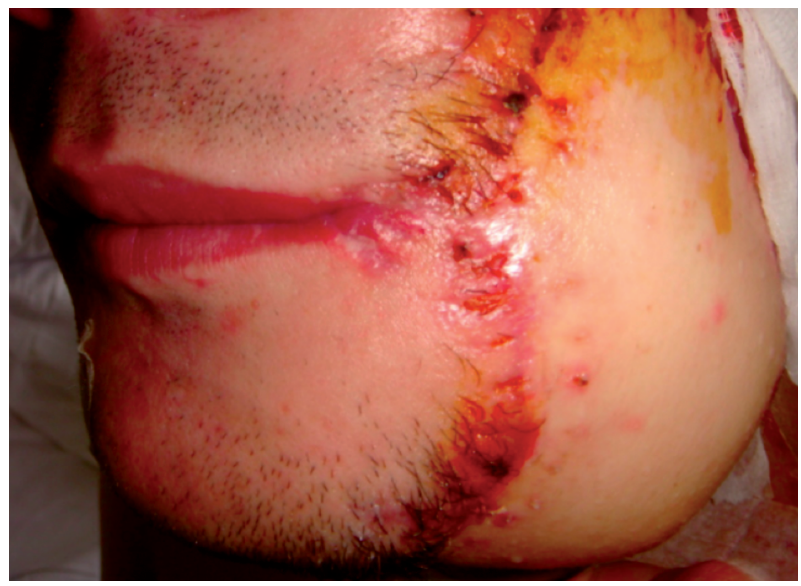

Figura 7. Aspecto extraoral postoperatorio a las dos semanas de la intervención del colgajo osteocutáneo escapular.

Figure 7. Postoperative extraoral aspect two weeks after the scapular osteocutaneous flap intervention.

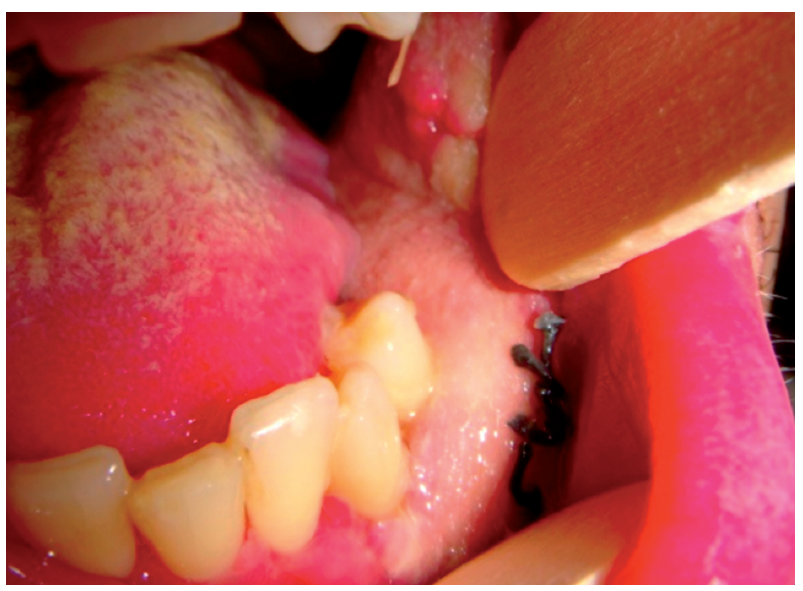

Figura 8. Aspecto intraoral postoperatorio a las dos semanas de la intervención del colgajo osteocutáneo escapular.

Figure 8. Postoperative intraoral aspect two weeks after the scapular osteocutaneous flap intervention. nique (which has been described in detail by many authors), 3,4 a clinical case is presented with discussion of the usefulness of this donor area in the deferred treatment of firearm wounds with abundant loss of substance.

\section{Scapular osteocutaneous} flap: technical details

The scapular-parascapular osteocutaneous free flap (SOF) occupies an important place in the microsurgical reconstruction of complex mixed cutaneous-mucosal-bony defects of the head and neck. The flap is based on the arterial axis consisting of the axillary artery, subscapular artery, scapular circumflex artery, and scapular-parascapular arteries.

These complex defects are found in injuries produced by firearms such as shotguns (hunting) and high-speed projectiles.

Once the decision is made to perform SOF, the flap generally is drawn the day before surgery on the patient, who is in standing position, with the torso bare and the arms hanging. The scapula on the side opposite the defect usually is used. The omotricipital triangle is located at the point where a line drawn horizontally from the highest part of the posterior axillary fold to the lateral edge of the scapula. Doppler ultrasonography can help to locate the arterial branches to be preserved.

On the day of the intervention, after the donor vessels (superior thyroid, lin- 
2. Colgajo osteocutáneo. Se conservan las siguientes ramas de la ACE:

- Pedículo nutrício óseo.

- Rama descendente.

Se seccionan:

- Rama del infraespinoso.

- Rama circunfleja anterior de la escápula para el músculo subescapular.

La osteotomía se hace debajo de la inserción del músculo tríceps braquial, dejando un ribete muscular de la inserción del músculo redondo menor, redondo mayor o subescapular. Puede sangrar la rama anterior de la ACE para el músculo subescapular. Como hemos comentado antes dejamos la arteria nutricia ósea y la rama descendente de la ACE. En profundidad encontramos los vasos toracodorsales y la unión de la ACE a dichos vasos formando los vasos subescapulares.

Es importante preservar el nervio toraco-dorsal.

Llegados a este punto elegimos el punto de disección del pedículo de la ACE individualizando la arteria y la vena para su ligadura independiente. Sobre la ACE cruza un puente venoso que une las dos venas del pedículo que es conveniente no dañar.

Se liga primero la arteria y luego la vena. Podemos ligar el "eje arterial" ACEArteria Subescapular arteria en dos puntos:

1. Ligadura en la ACE, es decir, antes de la bifurcación de la arteria toracodorsal (visto desde la perspectiva del cirujano). Pedículo de 7-10 $\mathrm{cm}$ y $2,53 \mathrm{~mm}$ de diámetro.

2. Ligadura en el tronco de la arteria subescapular. Para ello debemos ligar la arteria toracodorsal y progresar en profundidad por la arteria subescapular hasta su unión con la arteria axilar. Pedículo de hasta $11-14 \mathrm{~cm}$ y 3-4 mm de diámetro.

Se procede al cierre directo de la zona donante y cabestrillo para el brazo del lado intervenido durante dos semanas con rehabilitación posterior.

\section{Caso clínico}

Enfermo de 19 años que ingresa procedente de urgencias por herida por arma de fuego (escopeta de caza) tras intento de autolisis (distancia de impacto inferior a un metro). Presentaba una herida del tercio inferior región lateral con importante pérdida ósea de región desde primer premolar izquierdo hasta ángulo mandibular izquierdo. Pérdida cutáneo-mucosa importate de región yugal

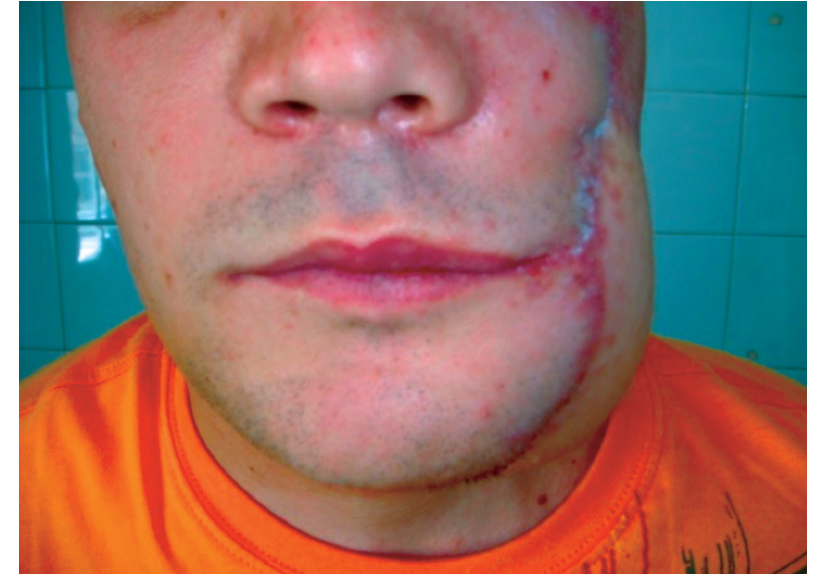

Figura 9. Aspecto clínico dos meses después de la intervención. Foto antero posterior.

Figure 9. Clinical appearance two months after surgery. Anteroposterior photograph.

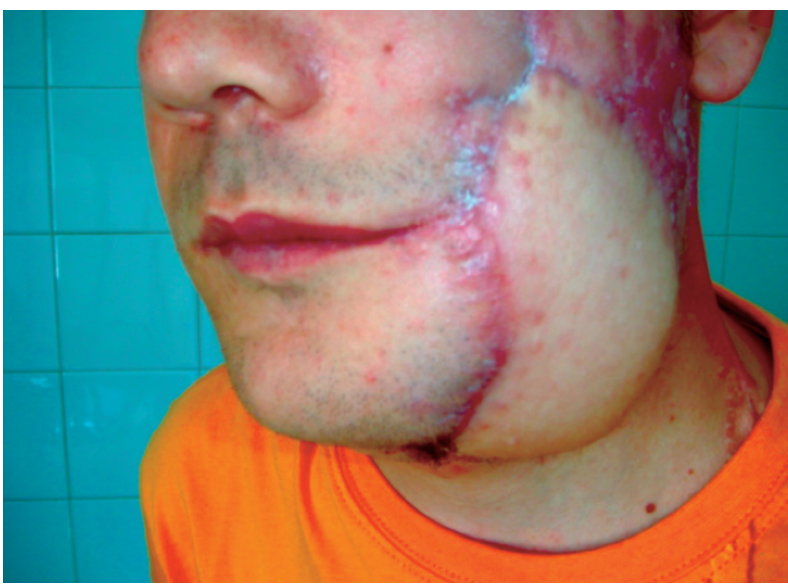

Figura 10. Foto lateral del paciente.

Figure 10. Lateral photograph of the patient. gual, or facial arteries) are dissected, the patient is placed in lateral prone position with the arm flexed $90^{\circ}$, perpendicular to the chest. It is useful to use an arm support and to tape the hip to the table in the proper position. The flap is raised from the distal point with the thoracolumbar fascia that covers the latissimus dorsi, teres major, teres minor, and trapezius muscles. The fascia of the infraspinatus and deltoid muscles is excluded. In the omotricipital triangle, the fascias are separated to probe deeper in the omotricipital space, which is limited by the teres minor fascia above and teres major fascia below. Laterally it is limited by the long head of the triceps brachii muscle. The lateral crest of the scapula is a landmark because the pedicle emerges immediately adjacent to it. We enter the loose areolar plane to section the direct vascular branches to the teres major muscle.

Near the lateral crest, our next actions depend on the type of flap being prepared:

1. Skin flap without bone (scapular-parascapular). We section the following branches of the scapular

2. circumflex artery $(S C A)$ :

- Pedicle of the bone nutrient artery.

- Descending branch.

- Branch of the infraspinatus.

- Anterior scapular circumflex branch for the subscapularis muscle.

3. Osteocutaneous flap. The following branches of the SCA are conserved:

- Pedicle of the bone nutrient artery.

- Descending branch.

The following arteries are sectioned:

1. Branch of the infraspinatus artery.

2. Anterior scapular circumflex branch for the subscapularis muscle.

An osteotomy is made below the insertion of the triceps brachii muscle, leaving a muscular rim of the insertion of the teres minor, teres major, or subscapularis muscle. There may be bleeding 
izquierda y mejilla izquierda. Se procede inicialmente a la realización de traqueotomía, desbridamiento de tejidos desvitalizados, ferulización dentaria, bloqueo intermaxilar y colocación de placa de reconstrucción mandibular (Figs. 1 y 2).

Se llevó a cabo, en este primer tiempo quirúrgico, un cierre directo intraoral y un cierre cutáneo con colgajo de avance cervicofacial.

En el postoperatorio inmediato se produce un sufrimiento y pérdida del colgajo cutáneo de avance cérvico-facial que deja una importante área granulante facial izquierda. La retracción cicatricial del tejido mucoso oral produce una gran limitación de la apertura oral $(0,8 \mathrm{~cm})$. Se manifiestan comunicaciones orofaciales y fístulas salivales.

Se decide intervención secundaria mediante un colgajo osteomiocutáneo escapular-paraescapular del brazo izquierdo, no dominante, pero con antecedente de luxación recidivante.

La intervención comienza con la nueva traqueotomía y la preparación de los vasos receptores: arteria facial y rama del tronco venoso tirolinguofacial. Es necesario extirpar una gran cantidad de tejido célulo-ganglionar del nivel I y III, para llegar a los vasos receptores.

Después se procede a la disección del colgajo osteocutáneo escapular-paraescapular, y al cierre de la zona donante, dejando drenaje aspirativo, e inmovilizando el miembro superior izquierdo con un cabestrillo (Figs. 3 y 4 ).

Seguidamente se adapta la parte ósea del colgajo al defecto mandibular con ostosíntesis usando la placa de reconstrucción colocada en la intervención inicial (Fig. 5). La parte cutánea de colgajo se dobla como si de un libro se tratara, quedando uno de los lóbulos cutáneos intraoral y otro extraoral (facial cervical). El dorso del supuesto libro se desepiteliza y se sutura al labio inferior remanente (Fig. 6). La parte intraoral reconstruye toda la mucosa yugal hasta el pilar anterior del velo del paladar. La parte externa reconstruye la zona cutánea mandibular y submandibular izquierda. La región posterosuperior del defecto cutáneo queda para injerto dermoepidérmico. Se retira el bloqueo y la férula dental y se deja la boca "abierta".

La adaptación del colgajo requiere submaxilectomía y extirpación de parte del tejido subcutáneo de la zona posteroinferior.

La anastómosis se hizo término-terminal de la arteria circunfleja escapular a la arteria facial; y de la mayor de las venas circunflejas escapulares al tronco tirolinguofacial.

La duración de la intervención fue de 14 horas; con un tiempo de isquemia de 2,45 horas.

Evolución satisfactoria respecto a la vitalildad del colgajo escapular. Complicaciones locales: fístula salival parotídea en zona posterosuperior por pérdida del injero dermoepidermico sobre región maseterina (Figs. 7 y 8 ).

Complicaciones en zona donante desinserción del brazo largo del tríceps y dehiscencia de herida. Para tratamiento de dicha dehiscencia se intervino el enfermo realizándose un cogajo local de transposición (Figs. 9 y 10). Complicación postural: parálisis del nervio radial del lado contralateral (derecho).

El enfermo sigue un tratamiento rehabilitador para recuperar la movilidad del brazo izquierdo. from the anterior branch of the SCA to the subscapularis muscle. As noted above, we leave the bone nutrient artery and descending branch of the SCA. Probing inwards we find the thoracodorsal vessels and the convergence of the SCA with these vessels, which together form the subscapular vessels.

It is important to preserve the dorsal cutaneous nerve.

When we reached this point we chose the point of dissection of the SCA pedicle, separating the artery and vein for ligation. A venous bridge crosses the SCA and joins the two veins of the pedicle, which should not be damaged.

The artery is ligated first and then the vein is ligated. The SCA-subscapularis artery "axis" is ligated at two points:

1. On the SCA, before the bifurcation of the thoracodorsal artery (as seen from the surgeon's perspective). This results in a pedicle $7-10 \mathrm{~cm}$ long by $2.5-3 \mathrm{~mm}$ diameter.

2. Ligation of the trunk of the subscapularis artery. The thoracodorsal artery is ligated and we continue inward along the subscapularis artery to its convergence with the axillary artery. This results in a pedicle up to $11-14 \mathrm{~cm}$ long by 3-4 mm diameter.

The donor zone is closed directly and the arm on the operated side is supported in a sling for two weeks followed by rehabilitation.

\section{Clinical case}

A 19-year-old male was admitted from the emergency department with a firearm wound (shotgun) after trying to commit suicide (impact distance less than one meter). He presented a wound of the lateral lower third of the face with major bone loss from the left first premolar to the left mandibular angle. He had a large cutaneo-mucosal defect in the left jugal and cheek region. The initial actions were tracheotomy, debridement of devitalized tissues, dental splinting, maxillomandibular fixation, and placement of a mandibular reconstruction plate.

In this first surgical stage, direct intraoral closure and skin closure with a cervicofacial advancement flap were performed.

In the immediate postoperative period, the cervicofacial advancement flap suffered and was lost, leaving a large area of facial granulation tissue on the left side. Scar retraction of the oral mucosa tissue restricted mouth opening $(0.8 \mathrm{~cm})$. Orofacial openings and salivary fistulas appeared.

A secondary intervention was decided on, which consisted in a scapular-parascapular osteomyocutaneous flap from the nondominant left arm because the patient had a history or recurrent shoulder dislocation.

The intervention began with a new tracheotomy and the preparation of the receptor vessels: the facial artery and branch of the thyrolinguofacial venous trunk. A large amount of level I and III cellular lymphatic tissue had to be excised in order to dissect the receptor vessels. 


\section{Discusión}

En general, los objetivos del tratamiento de las heridas por arma de fuego en la región facial son:

1. Vía aerodigestiva (nasal oral) permeable y funcional.

a. Buena apertura oral (4-5 cm), músculo orbicular de la boca funcional.

b.Cavidad nasal independiente y "anatómica".

c. Evitar fístulas orocervicales u orocutáneas.

d.Función deglutoria.

2. Preservación de órganos de los sentidos: estética y funcionalmente.

3. Separar VADS de cavidad craneal.

4. Reconstrucción ósea.

a. Mandibular. Importante para la función masticatoria y proyección del tercio inferior.

b.Maxilar y tercio medio. Importante para la función masticatoria y la estética del tercio medio facial.

c. Frontal. Con importancia estética fundamentalmente.

5. Cobertura cutáneo mucosa estética, evitando exposición ósea.

6. Rehabilitación dental implantosoportada (no siempre indicada).

En las heridas por proyectiles de baja velocidad en los que la pérdida de sustancia no es importante, ${ }^{5}$ generalmente puede hacerse un tratamiento primario definitivo, con osteosintesis de las fracturas y cierre directo o con colgajos locales.

En las heridas por arma de fuego de alta velocidad o por escopeta de caza con perdigones es frecuente una amplia pérdida de sustancia que requiere una evaluación cuidadosa y tratamiento secundario, sobretodo en la región del tercio inferior y lateral facia. Aunque hay magnificos magníficos artículos de revisión sobre reconstrucción mandibular, ${ }^{6}$ repasamos a continuación las posibilidades reconstrucitivas para partes blandas y hueso.

En el tratamiento de las partes blandas podemos hacer un cierre directo, podemos usar colgajos locales (lingual, nasogeniano, buccinador), colgajos regionales (pectoral mayor, trapecio, ECM, platisma), o bien colgajos libres (antebraquial, lateral braquial, lateral de muslo, etc.).

Para el tratamiento quirúrgico de defectos óseos mandibulares podemos seguir las siguientes estrategias: sin reconstrucción, placa de reconstrucción, injerto libre autógeno, 6,7 mandíbula alogénica (criopreservada), distracción mandibular segmentaria, colgajos regionales (osteomiocutáneo trapecial lateral), ${ }^{8}$ y colgajos libres: peroné, ${ }^{9}$ cresta ilíaca, ${ }^{10}$ escápula, ${ }^{3,4}$ radio. ${ }^{11}$

La técnicas de microcirugía son hoy en día superiores a los métodos tradicionales para la reconstrucción en la región de la cabeza y cuello en general y en el tercio inferior facial en particular.

Los colgajos microvascularizados basados en el eje subescapular pueden sustituir a la mayoría de colgajos libres en la reconstrucción facial. Podemos tallar los siguientes tipos de colgajos:

1. Colgajos de partes blandas: colgajo escapular, paraescapular, serrato o dorsal ancho. Colgajos músculocutáneos.

2. Colgajos óseos: colgajo osteocutáneo escapular paraescapular, colgajo osteomiocutaneo (escapular-paraescapular-oseo-latisimus dorsi-serrato, también llamado "megaflap"), colgajo óseo.
The scapular-parascapular osteocutaneous flap then was dissected and the donor zone was closed. Aspiration drainage was left in place and the left arm was immobilized in a sling.

Next, the bony part of flap was adapted to the mandibular defect with its osteosynthesis using the reconstruction plate inserted in the initial intervention. The cutaneous part of the flap was folded like a book, leaving one of the cutaneous lobes inside the mouth and the other outside the mouth (facio-cervical). The epithelium was removed from dorsal part of the "book," which was sutured to the residual lower lip. The intraoral part was used to reconstruct the entire jugal mucosa to the anterior pillar of the soft palate. The external part was used to reconstruct the left cutaneous mandibular and submandibular area. The posterosuperior region of the cutaneous defect was for the dermoepidermal graft. The maxillomandibular fixation and dental splint were removed and the mouth was left "open."

The flap adaptation required submaxillectomy and excision of part of the subcutaneous tissue of the posteroinferior area.

The scapular circumflex artery was anastomosed endto-end to the facial artery. The largest of the circumflex veins was anastomosed to the thyrolinguofacial trunk.

The duration of the intervention was 14 hours, with an ischemia time of 2.45 hours.

The evolution was satisfactory in terms of the vitality of the scapular flap. Local complications: posterosuperior parotid-salivary fistula due to loss of the dermoepidermal graft on the masseteric region.

Donor zone complication: deinsertion of the triceps long head and wound dehiscence. This dehiscence was treated surgically with a local transposition flap. Postural complication: contralateral (right) paralysis of the radial nerve.

The patient is undergoing rehabilitation to recover leftarm mobility.

\section{Discussion}

Generally speaking, the objectives of the treatment of firearm wounds in the facial region are:

1. To conserve the patency and functionality of the aerodigestive tract (naso-oral).

a. Good mouth opening $(4-5 \mathrm{~cm})$, functional orbicularis oris muscle.

b. Independent and anatomically correct nasal cavity.

c. Prevention of orocervical or orocutaneous fistulas.

d. Swallowing function.

2. Preservation of sensory organs: aesthetically and functionally.

3. Separate the aerodigestive space from the cranial cavity.

4. Bone reconstruction.

a. Mandible. Important for chewing function and projection of the lower third. 
Como colgajo osteocutáneo el colgajo escapular tiene como ventajas:

1. El gran aporte de tejidos blandos, la plasticidad tridimensional, longitud de hueso adecuada a la mayoría de defectos, y un pedículo largo y de buen calibre. Sobre todo cuando se incluye la arteria subescapular.

2. La piel escapular no tiene pelo, puede plegarse con facilidad en personas delgadas o ancianos.

3. Como ya hemos comentado la cantidad de hueso es suficiente, hasta $14 \mathrm{~cm}$, ampliables hasta 18 incluyendo en el colgajo la arteria angular rama de la tóracodorsal y la punta de la escápula.

El inconveniente principal es la imposibilidad del trabajo con dos equipos simultáneos. Lo que prolonga la cirugía, siendo necesarios además dos cambios posturales con la colocación de campos operatorios nuevos. El coste económico es superior como ya se ha puesto de manifiesto. ${ }^{12}$

Normalmente se talla el colgajo del lado contralateral al defecto porque así, al orientar el borde de la escápula hacia abajo, conseguimos que el pedículo vascular se acerque a los vasos receptores. No obstante, en este caso se usó el mismo lado de la lesión por los antecedentes patologicos previos del hombro, lo que nos obligó a invertir la posición del colgajo óseo en la reconstrucción mandibular. Esto último no afectó a la adaptación de las partes blandas o su viabilidad, ni tampoco creemos que dificulte la rehabilitación implantosoportada llegado el momento.

La adaptación ósea del colgajo con placa de reconstrucción con tornillos de bloqueo es importante, pero aún lo es más la adaptación de partes blandas que requiere una gran experiencia y gestos como el desgrasado del injerto o la submaxilectomía ipsilateral como ocurrió en este caso.

En nuestra experiencia (Cádiz-Granada con total de 15 enfermos) se usaron los colgajos del eje subescapular como donantes para recontrucción mandibular en caso de imposibilidad de primeras opciones (peroné, cresta ilíaca...) o en defectos que incluían partes blandas de espesor total por encima de la comisura, ${ }^{13}$ pero los buenos resultados obtenidos (2/15 pérdidas de colgajo: $13,3 \%$ ) compensan los inconvenientes por lo que creemos que deben considerarse de primera elección en reconstrucciones mandibulares con amplio defecto cutáneo-mucoso sobretodo laterales. Por ejemplo en heridas por arma de fuego. Esto ha sido ya comunicado en otros trabajos. ${ }^{14}$

La distracción osteogénica mandibular,15,16 y las proteinas morfogenéticas óseas (en fase de experimentación) ${ }^{17}$ podrían ser una altenativa en el futuro a la microcirugía en casos de defectos traumaticos como es el caso que nos ocupa o en neoplasias benignas que no hayan recibido radioterapia. Siempre y cuando no sea necesario el aporte de tejidos blandos para la reconstrucción tridimensional de defectos complejos como el presentado.

\section{Agradecimientos}

A Rosendo Mangas por sus correcciones del original. b. Maxilla and middle third of the facial massif. Important for chewing function and the aesthetically acceptable appearance of the middle third of the face.

c. Frontal. Fundamentally of aesthetic importance.

5. Aesthetically acceptable skin and mucosal coverage, avoiding bone exposure.

6. Implant-supported dental rehabilitation (not always indicated).

In wounds caused by low-speed projectiles in which the loss of substance is not important, ${ }^{5}$ definitive primary treatment can generally be provided by osteosynthesis of the fractures and closure directly or with local flaps.

In high-speed firearm or shotgun wounds, large tissue losses are common, which requires careful evaluation and secondary treatment, especially in the region of the lower third and side of the face. Although there are magnificent review articles on mandibular reconstruction (6), we briefly review the reconstructive possibilities for soft tissues and bone below.

Soft tissues can be treated by directly closure of the wound or the use of local flaps (lingual, nasogenial, buccinator), regional flaps (pectoralis major, trapezius, sternocleidomastoideus, platysma), or free flaps (antebrachial, lateral brachial, lateral thigh, or other).

The following strategies can be used for the surgical treatment of mandibular bone defects: no reconstruction or reconstruction using a plate, autologous free graft, 6,7 allogeneous mandible (cryopreserved), segmental mandibular distraction, regional flaps (lateral trapezial osteomyocutaneous)', and free flaps: fibula, ${ }^{9}$ iliac crest, ${ }^{10}$ scapula, ${ }^{3,4}$ radius. ${ }^{11}$

Microsurgical techniques are now superior to traditional methods for reconstructing the region of the head and neck in general and in the lower third of the face in particular.

Microvascularized flaps based on the subscapularis axis can replace most free flaps in the reconstruction of the face. The following types of flaps can be shaped:

1. Soft tissue flaps: scapular, parascapular, serratus, or latissimus dorsi flaps; musculocutaneous flaps.

2. Bone flaps: scapular parascapular osteocutaneous flap, osteomyocutaneous flap (scapular-parascapular-osteolatissimus dorsi-serratus, also called "megaflap"), bone flap.

The scapular flap has the following advantages as an osteocutaneous flap:

1. It provides abundant soft tissues, three-dimensional plasticity, bone length adequate for most defects, and a long pedicle of good caliber, particularly when it includes the subscapular artery.

2. The scapular skin is hairless and can be folded easily in thin or elderly people.

3. As noted, the amount of bone is sufficient, up to $14 \mathrm{~cm}$, and can be expanded up to $18 \mathrm{~cm}$ by including in the flap the angular artery, branch of the dorsal cutaneous artery, and the tip of the scapula. 


\section{Bibliografía}

1. Sánchez López JD, Martinez Castillo S, García Medina B, Budiño Carbonero S, Fernandez Solís ], Rojo Aliaga J. Heridas Faciales por arma de fuego. Actitud terapéutica. Rev Esp Cirug Oral Maxilofac 1999;21:3:154-64.

2. Torres Garzón L, Rodríguez Ruiz JA. Traumatología Facial. En: urgencias en Rodríguez Ruiz JA, y cols. Urgencias en Cirugía Oral y Maxilofacial. Servicio de Publicaciones de la Universidad de Cádiz 2003;65-95.

3. Sánchez Lorenzo J. Llorente JL, Camporro D, y Fueyo A. Colgajo libre escapular-paraescapular. En: Llorente Pendás JL, Suarez Nieto C. Colgajos libres en las recontrucciones de cabeza y cuello. Edit Garsi. 1997;90-98.

4. Rodríguez Ruiz JA, Rendón Infante I, Torres Garzón L, Modelo Pérez A, Budiño Carbonero S, Fortis Sánchez E. Reconstrucción oral mediante colgajos microvascularizados vasados en la arteria subescapular. Rev Esp Cirug Oral Maxilofac 2001;23:284-93.

5. Ramos Xavier L, Alves Crespo M, Soares de Oliveira CM, de Freitas Baldez. Tratamiento inicial de heridas por proyectil de arma de fuego. A propósito de un caso. Rev Esp Cir Oral Maxilofac 2008;30:115-20.

6. Ochandiano S, Navarro-Vila C, López Atalaya FJ, Cuesta M, Verdaguer JM, Barrios JM, Acero J, Salmerón Jl. Reconstrucción mandibular: pasado presente y futuro. Rev Esp Cir Oral Maxilofac 2002;24:75-91.

7. Foster R, Anthony J, Sharma A, Pogrel A. Vasculariced bone flaps versus nonvascularice bone grafts for mandibular reconstrucción: an outcome analysis of primary bony union and endosseous implant success. Head Neck 1999;21:6671.

8. Navarro-Vila C, Borja Morant A, Cuesta M, López de Atalaya F, Salmeron JI, Barrios JM. Aesthetic and funcional recontructión with the trapezius osseomyocutaneous flap and dental implants in oral cavity cancer patients. J Craneomaxilofac Surg 1996;24:322-9.

9. Hidalgo D. Fíbula free flap: a new method of mandible reconstruction. Plast Recontr Surg 1989;84.

10. Urken ML Buchbinder D, Costantino P, Sinha U, Okay D, Lawson W, Biller H. Oromandibular recontruction using microvascular composite flaps. Report of 210 cases. Arch Otolaryngol Head Neck Surg 1998;124:46-55.

11. Casado Pérez C. Colgajo libre antebraquial fasciocutáneo y osteofasciocutáneo radial. En: Llorente Pendás JL, Suarez Nieto C. Colgajos libres en las recontrucciones de cabeza y cuello. Edit Garsi 1997;109-17.

12. Talesnik A, Markowitz B, Calcaterra M Ahn C, Shaw W. Cost and outcome of osteocutaneous free tissue transfer versus pedicled soft tissue reconstruction for composite mandibular defects. Plast Reconst Surg 1996;97:1167-78.

13. Urken ML Composite free flaps in oromandibular recontructión. Review of the literature. Arch Otolaryngol Head Neck 1991;117:724-32.

14. Deschler DG, Hayden RE. The optimum method for recontrucción of complex lateral oromandibular-cutaneous defects. Head Neck 2000;22:674-9.

15. Ilizarov GA. Clinical application of the tensión-stress effect for limb lengthening. Clin Orthop 1990;250:8-26.

16. Mc Carthy JG, Schreiber J, Karp N y Cols. Lengthening the human mandible by gradual distraction. Plast Reconst Surg 1992;89:1-8.

17. Boyne PJ. Animal studies of the application of rhBMP-2 in maxillofacial recontruction. Bone 1996:19:83-92.
The main disadvantage is the practical impossibility for two teams to work simultaneously. This prolongs the operation and also requires two changes in patient posture and the preparation of new operating fields. The intervention is more expensive, as already has been mentioned. ${ }^{12}$

The flap usually is taken from the side opposite the defect because it is easier to approximate the vascular pedicle to the receptor vessels by orienting the edge of the scapula downwards. However, in this patient the flap was obtained from the same side as the injury due to a history of shoulder dislocation. This forced us to invert the position of the bone flap in the reconstruction of the mandible. This did not affect the adaptation of the soft tissues or their viability, nor do we believe that it will interfere with the implant-supported dental rehabilitation when the time comes.

The bone adaptation of the flap to the locking-screwaffixed reconstruction plate was important, but even more important was the adaptation of the soft tissues, which required a great deal of experience and actions such as defatting the graft or same-side submaxillectomy, as in this case.

In our experience (Cádiz-Granada and a total of 15 patients), flaps of the subscapular axis were used as donor areas for mandibular reconstruction when the first options were impossible (fibula, iliac crest) or the defects included total thickness soft tissues above the commissure. ${ }^{13}$ The good results obtained (2/15 flap losses: 13.3\%) outweighed the disadvantages, which is why we think that this intervention should be considered as first choice in mandibular reconstruction with large cutaneous-mucosal defects, particularly lateral, eg, firearm wounds. This opinion has been stated in other studies. ${ }^{14}$

Mandibular osteogenic distraction 15,16 and osseous morphogenetic proteins (currently in the experimentation phase) 17 could be an alternative to microsurgery in the future for benign traumatic defects, such as the case reported here, or neoplasms that have not been irradiated, as long as a supply of soft tissue is not required for the three-dimensional reconstruction of complex defects like our case.

\section{Acknowledgments}

We thank Rosendo Mangas for correcting the original manuscript. 